Prepared in cooperation with the U.S. Department of Agriculture, Natural Resources Conservation Service

\title{
Estimating Potential Wetland Extent along Selected River Reaches in Indiana using Streamflow Statistics and Flood- Inundation Mapping Techniques
}

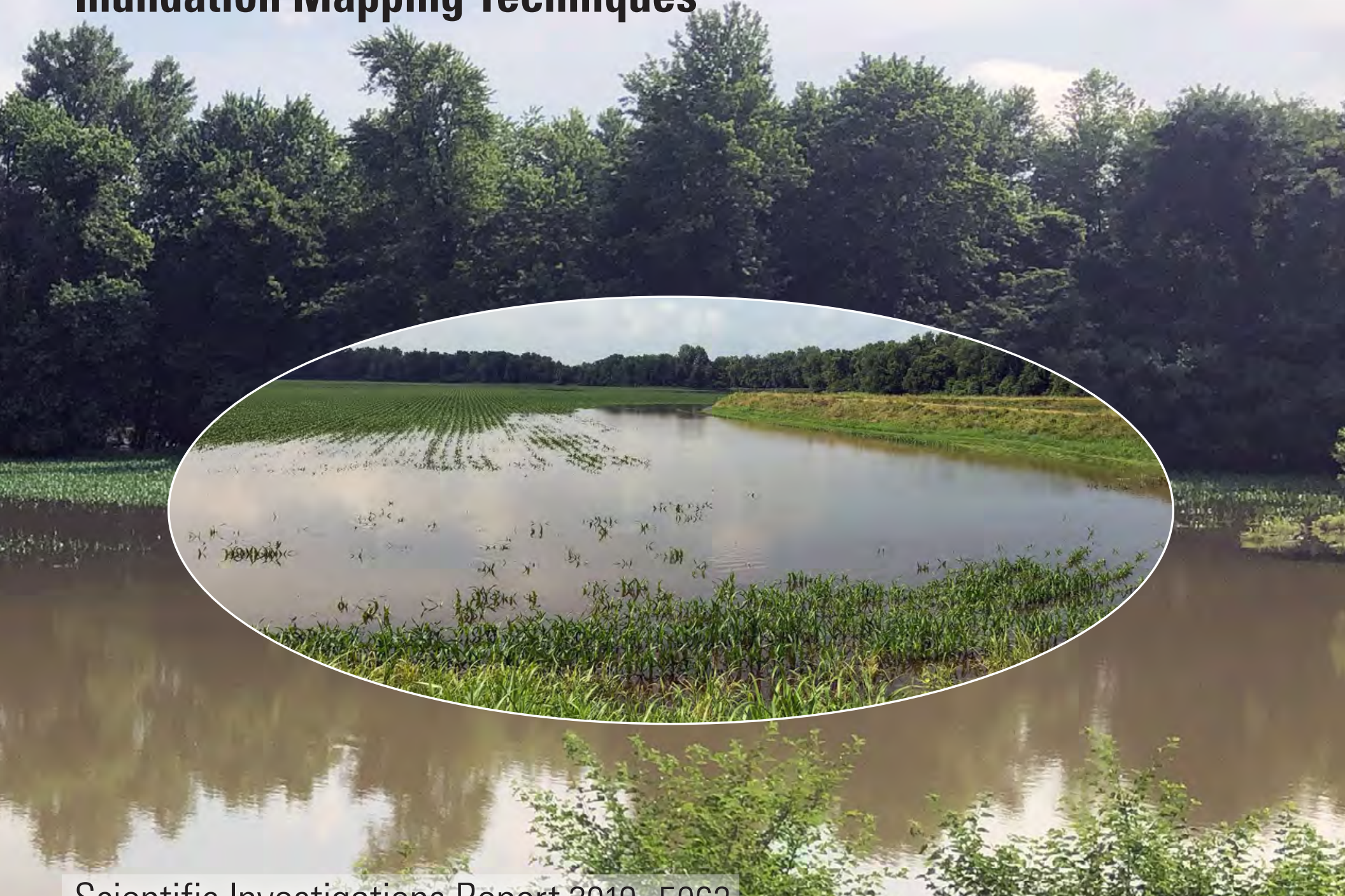

Scientific Investigations Report 2019-5063

U.S. Department of the Interior U.S. Geological Survey 
Cover. Flooded corn field adjacent to the White River in Knox County, Indiana. Photographs by Madelyn Messner, U.S. Geological Survey, June 19, 2019. 


\section{Estimating Potential Wetland Extent along Selected River Reaches in Indiana using Streamflow Statistics and Flood-Inundation Mapping Techniques}

By Kathleen K. Fowler, Benjamin J. Sperl, and Moon H. Kim

Prepared in cooperation with the U.S. Department of Agriculture, Natural Resources Conservation Service

Scientific Investigations Report 2019-5063 


\title{
U.S. Department of the Interior DAVID BERNHARDT, Secretary
}

\author{
U.S. Geological Survey \\ James F. Reilly II, Director
}

U.S. Geological Survey, Reston, Virginia: 2019

For more information on the USGS - the Federal source for science about the Earth, its natural and living resources, natural hazards, and the environment-visit https://www.usgs.gov or call 1-888-ASK-USGS.

For an overview of USGS information products, including maps, imagery, and publications, visit https://store.usgs.gov.

Any use of trade, firm, or product names is for descriptive purposes only and does not imply endorsement by the U.S. Government.

Although this information product, for the most part, is in the public domain, it also may contain copyrighted materials as noted in the text. Permission to reproduce copyrighted items must be secured from the copyright owner.

Suggested citation:

Fowler, K.K., Sperl, B.J., and Kim, M.H., 2019, Estimating potential wetland extent along selected river reaches in Indiana using streamflow statistics and flood-inundation mapping techniques: U.S. Geological Survey Scientific Investigations Report 2019-5063, 12 p., https://doi.org/10.3133/sir20195063.

ISSN 2328-0328 (online) 


\section{Contents}

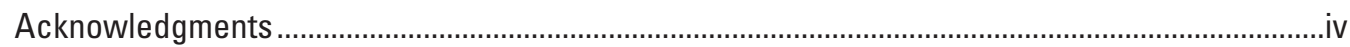

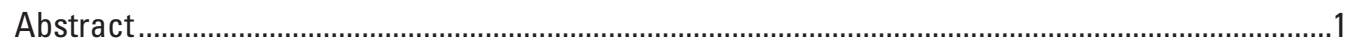

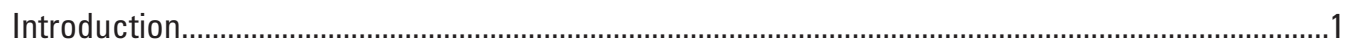

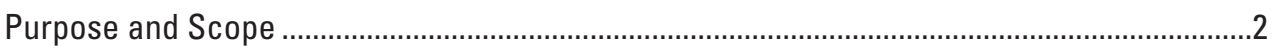

Previous Study.

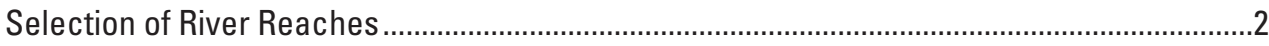

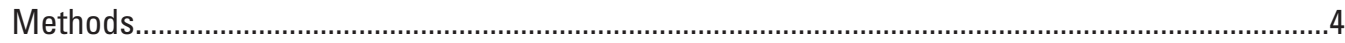

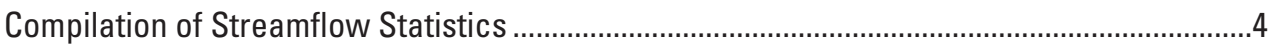

Estimation of Water-Surface Elevations .........................................................................

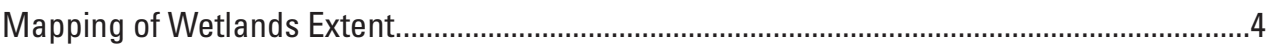

Geoprocessing Tools ..................................................................................................

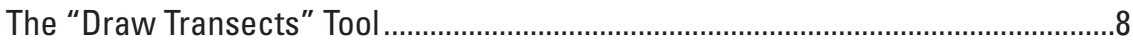

The "Delineate Wetlands" Tool .................................................................................

Validation of Estimated 7M02 Profiles ...............................................................................

Uncertainties and Limitations Regarding Use of Wetland Inundation Maps ..........................10

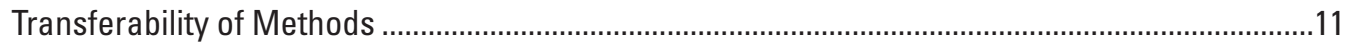

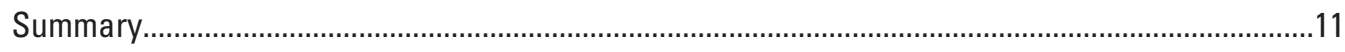

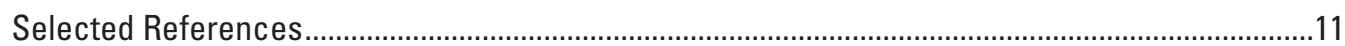

\section{Figures}

1. Map showing location of selected river reaches in Indiana, Ohio, and Illinois.................3

2. Map showing location of the study reach for the Flatrock River between Columbus and St. Paul, Indiana, and mapped extent of inundation from 7M02

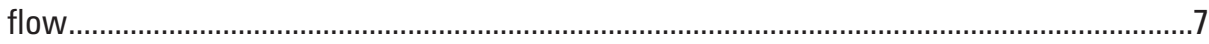

3. Graph showing comparison of historical flood profile elevations to estimated 7M02 elevations along the Kankakee River in Indiana ..................................................9

4. Graph showing comparison of historical flood profile elevations to estimated $7 \mathrm{MO} 2$ and 7M02 using high-water mark elevations along the East Fork White River in Indiana

\section{Tables}

1. Calculated values of inundation flows and corresponding inundation elevations at selected U.S. Geological Survey streamgages along the river reaches............................5

2. River reaches that required the use of high-water marks for calibration of the $7 \mathrm{M} 02$ profile 


\section{Conversion Factors}

U.S. customary units to International System of Units

\begin{tabular}{|c|c|c|}
\hline Multiply & By & To obtain \\
\hline \multicolumn{3}{|c|}{ Length } \\
\hline foot $(\mathrm{ft})$ & 0.3048 & meter $(\mathrm{m})$ \\
\hline mile (mi) & 1.609 & kilometer $(\mathrm{km})$ \\
\hline \multicolumn{3}{|c|}{ Area } \\
\hline acre & 4,047 & square meter $\left(\mathrm{m}^{2}\right)$ \\
\hline acre & 0.4047 & hectare (ha) \\
\hline acre & 0.004047 & square kilometer $\left(\mathrm{km}^{2}\right)$ \\
\hline square mile $\left(\mathrm{mi}^{2}\right)$ & 259.0 & hectare (ha) \\
\hline square mile $\left(\mathrm{mi}^{2}\right)$ & 2.590 & square kilometer $\left(\mathrm{km}^{2}\right)$ \\
\hline \multicolumn{3}{|c|}{ Flow rate } \\
\hline cubic foot per second $\left(\mathrm{ft}^{3} / \mathrm{s}\right)$ & 0.02832 & cubic meter per second $\left(\mathrm{m}^{3} / \mathrm{s}\right)$ \\
\hline
\end{tabular}

Vertical coordinate information is referenced to the North American Vertical Datum of 1988 (NAVD 88).

Horizontal coordinate information is referenced to the North American Datum of 1983 (NAD 83).

Elevation, as used in this report, refers to distance above the vertical datum.

\section{Abbreviations}

7M02 annual highest 7-consecutive-day mean discharge with a 2-year recurrence interval

ACEP Agricultural Conservation Easement Program

DEM digital elevation model

Esri Environmental Systems Research Institute

GIS geographic information system

NRCS Natural Resources Conservation Service

USGS U.S. Geological Survey

WRP Wetland Reserve Program

\section{Acknowledgments}

The authors wish to thank the U.S. Department of Agriculture, Natural Resources Conservation Service, for the funding of this study. Special thanks are given to Christian T. Ritz, Chris Morse, and Kenny Streett of the Natural Resources Conservation Service, Indianapolis office, for their review and valuable input throughout the entire study. 


\title{
Estimating Potential Wetland Extent along Selected River Reaches in Indiana using Streamflow Statistics and Flood- Inundation Mapping Techniques
}

\author{
By Kathleen K. Fowler, Benjamin J. Sperl, and Moon H. Kim
}

\section{Abstract}

In this study potential wetland extents were estimated for 12 river reaches covering about 750 river miles in Indiana and parts of Illinois and Ohio. The study was completed by the U.S. Geological Survey in cooperation with the U.S. Department of Agriculture, Natural Resources Conservation Service. This study follows and adds to the work completed in a pilot study and determines that potential wetland extents can be estimated using streamflow statistics, streamgage data, and flood-inundation mapping techniques.

The study was designed to assist in the Agricultural Conservation Easement Program. The Agricultural Conservation Easement Program is a voluntary program administered by the Natural Resources Conservation Service that provides technical and financial assistance to private landowners and Tribes to restore, protect, and enhance wetlands in exchange for retiring eligible land from agriculture. For a site to be eligible for wetland restoration, it should be in a zone with sustained or frequent flooding. This study calculated the flows that lasted for a period of 7 consecutive days on average at least once every 2 years (a value termed the "7MQ2") for all the U.S. Geological Survey streamgages within the selected river reaches. These 7MQ2 flows were related to the stage-discharge tables for each streamgage, and a corresponding water-surface elevation was determined. Maps of estimated wetland extent were prepared using the 7MQ2 inundation elevation data in conjunction with bare-earth land-surface elevation data made publicly available through the online geospatial data clearinghouses of Indiana, Illinois, and Ohio. Flood-inundation mapping techniques were applied with the aid of geographic information system software to generate water-surface planes that represent inundation elevations associated with the 7MQ2 streamflow. Land-surface elevation data from high-resolution digital elevation models were subtracted from the watersurface planes to produce maps of wetland extent. The 12 map products, including datasets and geoprocessing tools, produced from this study will aid the National Resources Conservation Service and its partners with the onsite inundation-zone verification in agricultural land for potential restoration.

\section{Introduction}

Wetlands are transitional areas of land between terrestrial and deeper-water habitats like rivers or streams. They can be vegetated or barren, but the water table is commonly at or near the land surface or the area can be covered with water. Wetlands are classified by hydrology, vegetation, and substrate (Cowardin and others, 1979). This report concentrates on the hydrology classification.

Wetlands provide benefits to surrounding ecosystems by serving numerous hydrological and ecological functions. Reducing streamflow velocity and flood peaks is a flood control method that can be implemented near wetlands by storing water temporarily and releasing it gradually. Wetlands improve water quality because they absorb excess nutrients that can degrade ground and surface water. Stream channels can be maintained by stabilizing the land surface with a variety of vegetation that grows well in wetlands. Wetlands serve as habitat for many animals, migrating birds, and diverse plant life (Indiana Department of Natural Resources, 1996). Wetlands also can be valuable assets because they provide educational, economic, and recreational activities such as boating, swimming, hiking, birding, fishing, and hunting. Interest in the conservation and management of wetlands has increased because their function and value to the environment and society have become better understood (U.S. Geological Survey, 1996).

Wetlands are an important part of the Nation's natural resources; however, during a period of about 200 years, from the 1780 s to the $1980 \mathrm{~s}$, the total estimated loss of wetlands in the conterminous United States was about 53 percent, from about 221 million acres to about 104 million acres (Dahl, 1990). During the same time, Indiana lost about 87 percent of its wetlands, decreasing from about 5.6 million acres to about 751,000 acres (Indiana Department of Natural Resources, 1996). Wetlands in Indiana and across the country were being lost at a rate of about 1-3 percent each year, mainly because of drainage for agricultural purposes (U.S. Geological Survey, 1996); however, during 1998-2004, the trend was reversed. Studies completed by the U.S. Fish and Wildlife Service 
indicate that wetland gains have surpassed wetland losses, and the United States is gaining about 32,000 acres of wetlands each year. The increase is due to agricultural conservation plans, wetland restoration, land retirement programs, and the construction of freshwater ponds (U.S. Fish and Wildlife Service, 2004). The Natural Resources Conservation Service (NRCS) also notes an increase in wetlands from 1997 to 2007 in the 2010 Summary Report (U.S. Department of Agriculture, 2013).

The Agricultural Conservation Easement Program (ACEP) was established by the Agricultural Act of 2014. It repealed the Wetland Reserve Program (WRP) created by the 1990 Food, Agriculture, Conservation, and Trade Act but did not affect the validity or terms of any WRP contract entered into before February 7, 2014. Like the WRP, the ACEP is a voluntary program, administered under the U.S. Department of Agriculture, NRCS, that provides technical and financial assistance to private landowners to restore, protect, and enhance wetlands in exchange for retiring eligible land from agriculture (U.S. Department of Agriculture, 2017). Landowners can contact their local NRCS office if they are interested in participating in the ACEP. If an agricultural land contains degraded wetlands that have a high chance for successful restoration, the land may be eligible for participation. The hydrology criteria for an agricultural site to be eligible for wetland restoration require that the land be in a zone with sustained or frequent flooding for a period of 7 consecutive days on average at least once every 2 years (a flow statistic called the "7MQ2") or be saturated for at least 14 days during the growing season. If an agricultural site meets these criteria, and is selected for participation, the NRCS develops a restoration plan and makes an offer to the landowner (U.S. Department of Agriculture, 2007). For this study, the focus was on the $7 \mathrm{MQ} 2$ criterion only. Because this flow statistic represents the mean value of the 7-day high flow, it necessarily represents an estimate that is conservative. The estimated inundation area probably would not be under water for the entire 7 days. Areas that could be inundated are less likely to be missed using this statistic.

In this study, wetland extents were estimated for 12 river reaches covering about 750 river miles in Indiana and parts of Ohio and Illinois. The river reaches were selected by the NRCS and the U.S. Geological Survey (USGS) as river basins that contain two or more USGS streamgages and are in areas where potential wetland information is needed for restoration under the ACEP.

\section{Purpose and Scope}

This report presents the methods used to estimate the potential wetland extents for 12 river reaches in Indiana and parts of Ohio and Illinois (fig. 1). New methods were needed to expand the library of maps used by the NRCS in determining agricultural areas that can be restored to wetlands. The methods for map preparation are documented, and the datasets used in all calculations are available through a USGS data release at https://doi.org/10.5066/P9LGXDJ8 (Fowler and others, 2019). In addition to the data release, the library of maps produced by this study can also be viewed through an Esri story map at https://wim.usgs.gov/geonarrative/ indianawetlands/.

\section{Previous Study}

In 2012, a pilot study was completed by the USGS in cooperation with the NRCS to document that potential wetland extents can be estimated using streamflow statistics and flood-inundation mapping techniques (Kim and others, 2012). The pilot study was done to assist the NRCS and its staff in planning a wetland restoration following the WRP guidelines. Several criteria must be satisfied regarding vegetation, soils, and hydrology before a site in agricultural land area is deemed to be a wetland and considered for restoration. The pilot study focused on the hydrology criterion of the WRP guidelines, which requires determination and identification of areas indicating evidence of sustained or frequent flooding for a period of 7 consecutive days at least once every 2 years on average. The stream reach selected for the study was the Wabash River near Terre Haute, Indiana.

Upon completion of the pilot study, the NRCS and USGS realized the need for an expanded study that would furnish datasets for additional river reaches in Indiana where new requests for wetland restoration were being submitted by agricultural land owners. This need would require that the aging computer scripts used in the pilot study (Kim and others, 2012) be updated because they were written in the ARC Macro Language and are no longer fully supported by Esri; thus, the fundamental methods of the pilot study were incorporated into the programming of a new set of geoprocessing tools implemented in an ArcGIS Python Toolbox (.pyt).

\section{Selection of River Reaches}

A total of 12 river reaches were selected by the NRCS and the USGS as river basins that contain 2 or more USGS streamgages and are in areas where potential wetland information is needed for restoration under the ACEP (fig. 1). Each streamgage was required to have at least 10 years of record to provide enough data to determine streamflow statistics and have an established rating curve from which to obtain the stage/discharge relation. In addition to streamgages, highresolution elevation data were needed. Indiana currently (since 2011) has high-resolution elevation data (Woolpert, 2011), and all river reaches in the State were included in the new digital elevation models (DEMs). For areas in Ohio, elevation data were obtained from the Ohio Office of Information Technology (Ohio Geographically Referenced Information Program, 2018). Illinois elevation data were downloaded from the Illinois Natural Resources Geospatial Data Clearinghouse, Illinois State Geological Survey (2018). Historical flood profiles from the Indiana Department of Natural Resources were used to check the estimated 7MQ2 elevations along each reach. 


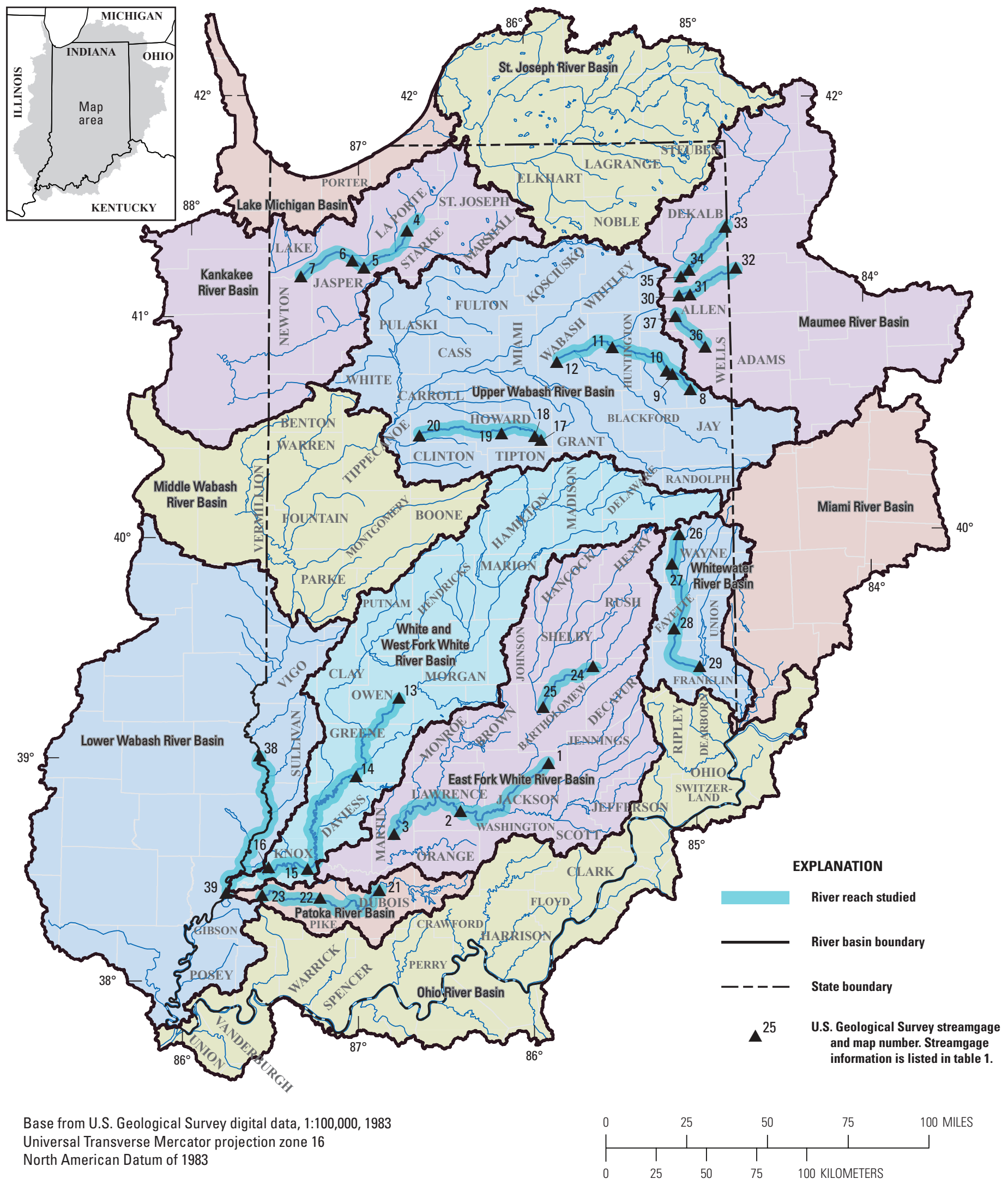

Figure 1. Location of selected river reaches in Indiana, Ohio, and Illinois. 


\section{Methods}

Procedures were developed to determine streamflow and water-surface elevation along selected reaches in Indiana to allow estimation of inundation elevations and inundation extent that meet the ACEP planning guidelines. The procedure consists of three steps: (1) compilation of streamflow statistics, (2) estimation of water-surface elevations based on streamflow statistics, and (3) mapping of estimated wetland extents.

\section{Compilation of Streamflow Statistics}

The ACEP planning guidelines state that to meet the planning criteria for restoring agricultural land to wetlands, a site needs to provide evidence of being in an area prone to sustained or frequent flooding for a period of 7 consecutive days at least once every 2 years on average or be saturated for at least 14 days during the growing season. The evidence can be obtained through statistical analysis of daily mean discharges computed from the historical records of USGS streamgages. The statistical value generated by this analysis is the annual highest 7-consecutive-day mean discharge with a 2 -year recurrence interval. The 7MQ2 at a streamgage serves as a determination of the inundation flow at that location. Daily mean discharges for the streamgages used in this study are stored in the USGS National Water Information System at https://waterdata.usgs.gov/nwis. Based on those daily mean discharges, the set of annual highest 7-consecutive-day mean discharges was calculated for each streamgage. The water year rather than the calendar year was used as the annual period for this flow statistic. A water year is defined as the 12-month period from October 1 to September 30 and is designated by the year in which it ends. By separating annual periods at the time of year when discharges are generally low, the high flows can be analyzed with a greater degree of continuity.

The set of annual highest 7-consecutive-day mean discharges at each streamgage was used for the frequency analysis. Frequency curves relate the magnitude of a variable to the frequency of occurrence (Riggs, 1968). For this frequency analysis, the 7-consecutive-day mean discharge time-series data were analyzed using a log-Pearson Type-III distribution, as implemented in the USGS software package SWToolbox (Kiang and others, 2018).

This frequency analysis produced the 7MQ2, which was used as the inundation flow. Resulting data for streamgages along the selected river reaches are listed in table 1. For the streamflow data to better represent current conditions, the datasets included only those years after installation of floodcontrol reservoirs upstream from the river reaches (Ruddy and Hitt, 1990). The datasets for each streamgage are available in the data release (Fowler and others, 2019). Locations and other information regarding the streamgages can be found in the National Water Information System (U.S. Geological Survey, 2018a).

\section{Estimation of Water-Surface Elevations}

Water-surface elevations corresponding to the 7MQ2 streamflow were determined using the active or most recent stage-discharge relation for each of the selected streamgages at the time of this study (table 1). This relation is commonly referred to as the "rating" and is developed based on periodic, in-situ measurements of stage and discharge by hydrologic technicians (Rantz and others, 1982). Values of stage are derived from the rating and added to the vertical datum of the streamgage, effectively converting stage to inundation elevations that are referenced to the North American Vertical Datum of 1988 (NAVD 88). Conversion of stage to an elevation is necessary to make the data comparable among sites.

\section{Mapping of Wetlands Extent}

Maps of estimated wetland extent were prepared using USGS streamflow-derived inundation elevation data that meet the planning criteria for the ACEP in conjunction with publicly available bare-earth land-surface elevation data from the online geospatial data clearinghouses of Indiana, Illinois, and Ohio. Flood-inundation mapping techniques were applied with the aid of geographic information system software to generate water-surface planes that represent inundation elevations associated with the 7MQ2 streamflow. Land-surface elevation data from high-resolution digital elevation models were subtracted from the water-surface planes to produce maps of wetland extent.

A total of 12 wetland inundation maps were prepared. The raster and vector files for each study reach are available as a data release at https://doi.org/10.5066/P9LGXDJ8 (Fowler and others, 2019). Of the 12 reaches, 1 is along the Flatrock River and is shown in figure 2. The blue area is the estimated inundation extent of the 7MQ2 flow and is the hydrologic component of the criteria used to determine eligibility in the ACEP. Using such a map, property owners and the NRCS could evaluate the potential for removing land from agricultural uses and restoring that land back to a wetland.

\section{Geoprocessing Tools}

Two scripts named "Draw Transects" and "Delineate Wetlands" were written and configured as geoprocessing tools in an ArcGIS Python toolbox (.pyt) so that the workflow could be carried out in a semiautomated manner with user input required to initialize tool parameters. The parameters were refined by examining the output after each successive run. Development of the toolbox was in part motivated by a need to make the workflow more time efficient, but also to allow reproducibility of the results and to improve documentation. The grouping of processing tasks into separate tools reflects a natural break in the workflow whereby the output from the "Draw Transects" tool is examined before being used as input to execute the "Delineate Wetlands" tool. Both tools rely 


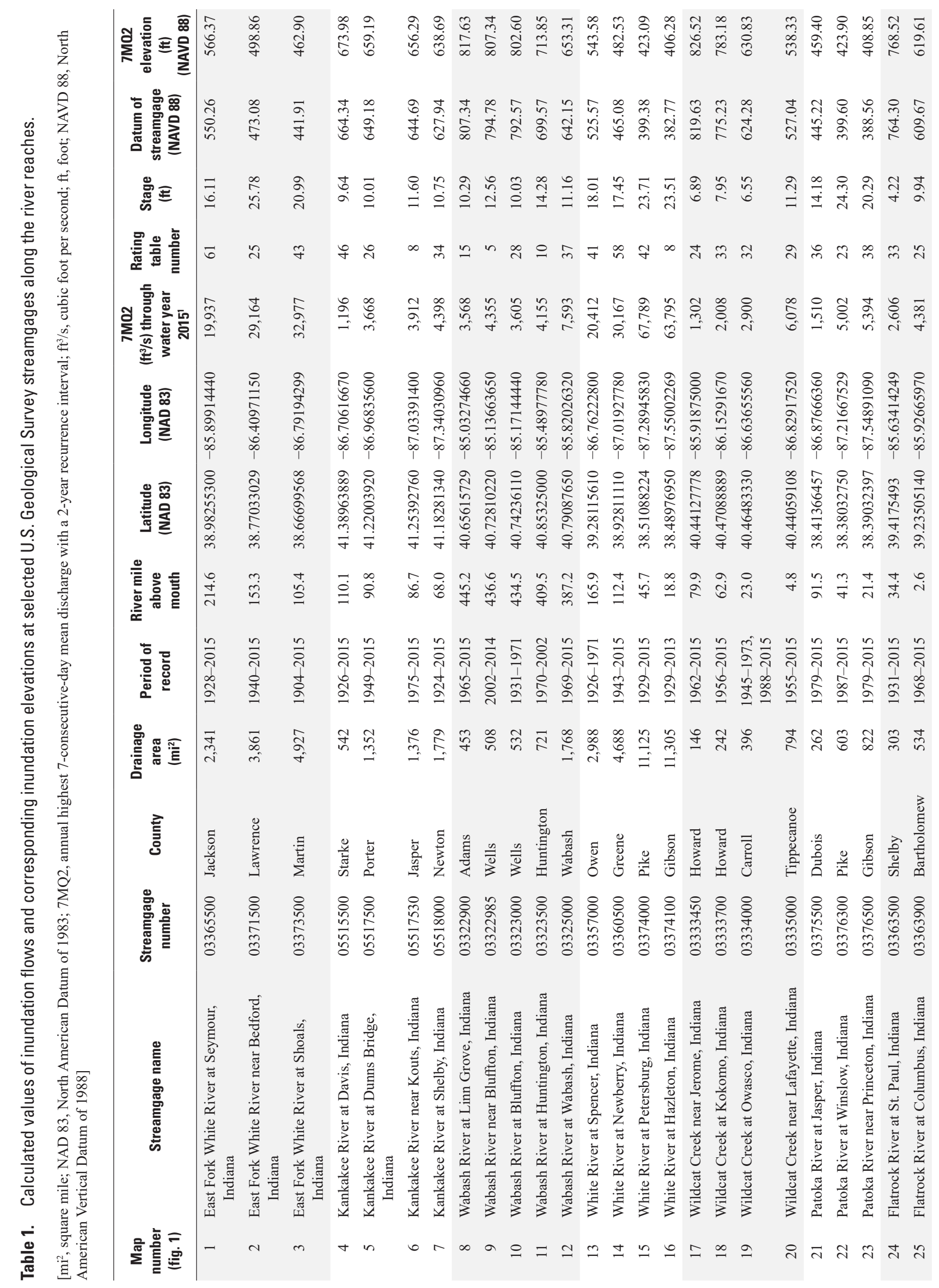




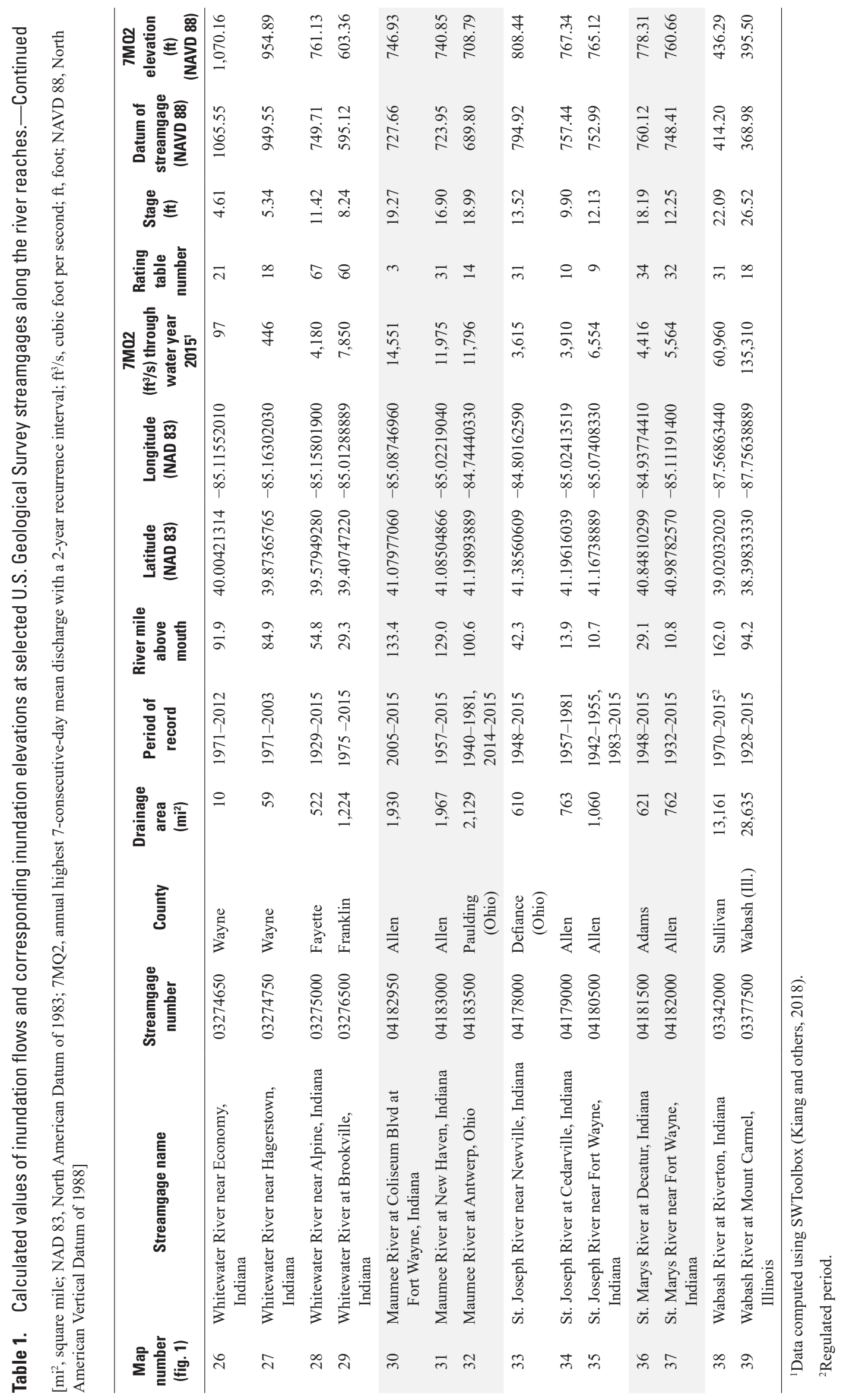



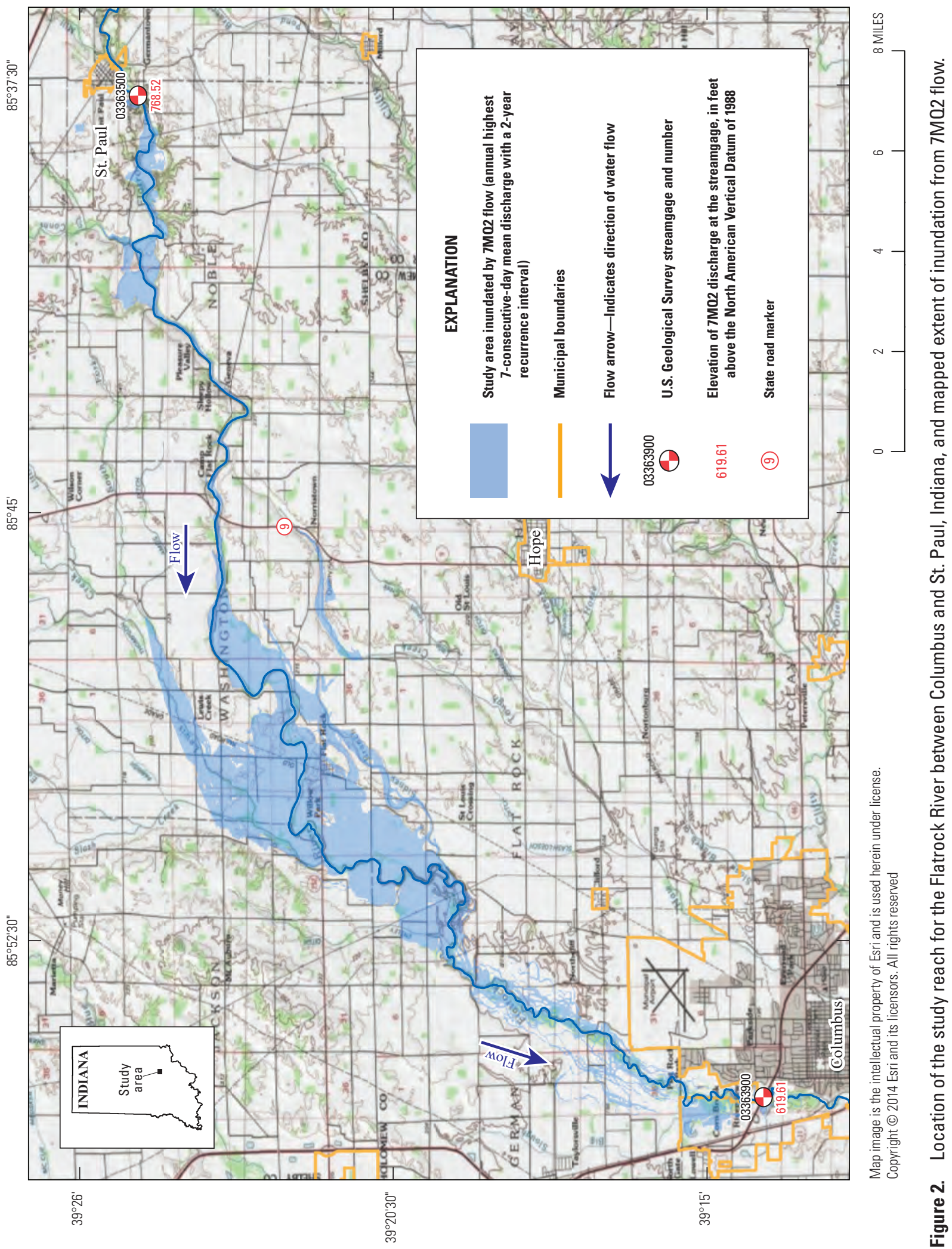
heavily on modules in the ArcPy site package, included with an ArcGIS Desktop license, but also leverage several other packages in the standard library distributed with Python. The conceptual underpinnings of these tools are described, though the toolbox is not released with this report. The toolbox was designed and developed for use by the NRCS to aid in determining areas eligible for restoration under the ACEP.

\section{The “Draw Transects” Tool}

Data from two primary sources are needed to run this tool: (1) flowlines from the National Hydrography Dataset (U.S. Geological Survey, 2017), which are extracted based on the name of the stream as it appears in the Geographic Names Information System (U.S. Geological Survey, 2018b) and dissolved into a single polyline feature, and (2) water-surface elevations that are associated with the 7MQ2magnitude streamflow computed from historical data at USGS streamgages. Optionally, 7MQ2 elevations at ungaged locations may be estimated and used to supplement USGS streamgages where coverage is sparse to ensure that critical inflection points in the water-surface profile are captured. Inflections in the slope of the water surface commonly occur at artificial control structures such as low-head dams, reservoirs, and transportation embankments but also occur naturally with topographic changes in the drainage basin. Historical flood profiles compiled from high-water marks serve as a useful reference in identifying where these inflection points occur. Taking 7MQ2 water-surface elevation data as input, the "Draw Transects" tool completes a stepwise-linear interpolation at points generated along the stream polyline at an equal-interval defined by the user. In practice, this interval was generally set to 500 feet.

Flow direction azimuths ( $0-360$ degrees) are calculated for each equal-interval point as the direction of a straight line connecting it to the next point downstream. A second set of flow direction azimuths is calculated at a more global scale by first smoothing the geometry of the stream polyline using a moving average on the $\mathrm{x}$ - and $\mathrm{y}$-coordinates of the equalinterval points, then repeating the same calculation as before. Calculating global azimuths in this way is necessary to determine the predominant direction of flow of the stream. These azimuths aid in the drawing of transects that are perpendicular to the direction of flow near the stream's main channel and the predominant direction of flow through the broader fluvial plain.

For the stream reaches modeled in this study, the primary consideration in determining an appropriate value for the length of transects was to ensure that they cross the entire 100-year flood plain. The 7MQ2 streamflow is lesser in magnitude than a 100-year event; therefore, transects crossing the entire 100-year flood plain also will cover the extent of wetlands. Before the "Draw Transects" tool was run, the width of the flood plain was measured at a sample of locations along the stream reach using ArcGIS software, and from those measurements, an appropriate value for transect length was determined.
Once drawn, transects are attributed with the 7MQ2 elevations of their respective points on the stream polyline and densified with additional vertices at the same equal interval. Transects that cross over the stream polyline more than once are deleted, and intersecting transects are deleted iteratively until there are no more intersections to ensure the logical consistency of transects drawn throughout the study area." After this step, the densified vertices of transects are converted to point features and used to generate a triangulated irregular network, which is then converted to a raster format producing a continuous, planar model of the 7MQ2 water surface sloped in the downstream direction of flow.

\section{The “Delineate Wetlands" Tool}

The "Delineate Wetlands" tool completes the process by subtracting the land-surface elevation data from the rasterized $7 \mathrm{MQ} 2$ water surface produced by "Draw Transects" tool in a digital elevation model covering the full extent of the study area. The result is an Esri Grid named "depth7mq2," which represents the extent and depth of inundation associated with the 7MQ2 streamflow. Cells with depth values greater than zero are extracted and converted to a polygon feature class named "extent_7mq2" that represents potential wetland extent in vector format. No edits were made to the "extent_7mq2" feature class post processing. In places the "extent_7 $\mathrm{mq} 2$ " feature class may contain polygons in extraneous areas such as adjacent streams or topographic depressions that are outside the flood plain of the target stream reach. Users may choose to review the feature class for areas that may have been inadvertently inundated because of transects extending beyond the immediate wetland area of the target stream reach.

\section{Validation of Estimated 7M02 Profiles}

The validity of a 7MQ2 profile was analyzed by graphically superimposing it with profiles of the stream's thalweg and historical floods. In checking the 7MQ2 profile for validity, several conditions were evaluated:

- Is the 7MQ2 profile above the thalweg throughout the entire stream reach?

- Is the 7MQ2 profile below historical flood events of greater magnitude?

- Are there any artificial control structures unaccounted for in the 7MQ2 profile?

- Does the slope of the 7MQ2 profile generally follow that of historical floods?

A profile comparison where none of the conditions are violated is shown in figure 3 . The reach of the Kankakee River shown has no artificial control structures, and the $7 \mathrm{MQ} 2$ profile follows the same general slope as the historical floods. If the 7MQ2 profile was found to violate one or more of these conditions, then high-water marks from a historical 
flood were used to supplement the elevations contributed by USGS streamgages as input in the geoprocessing workflow. The selected study reach for the East Fork White River is shown in figure 4 . This graph illustrates that although the slope of the 7MQ2 profile (yellow line) is similar to the thalweg (light green line), it omits critical inflection points in the historical flood profile (dark blue line). When highwater marks were used to supplement the data points, a more reasonable 7MQ2 profile was produced (red line).
Historical floods that best represent the hydrology of a stream reach in its present state were used to necessitate the selection of historical floods that occurred after the construction of a dam if one presently exists on the stream reach.

Locations, rather than the number of high-water marks used to supplement streamgage data, were of primary importance. Those at or near major inflections in the slope of the water surface were of greater value than those on parts of the stream with unchanging slope. To adjust the elevations of

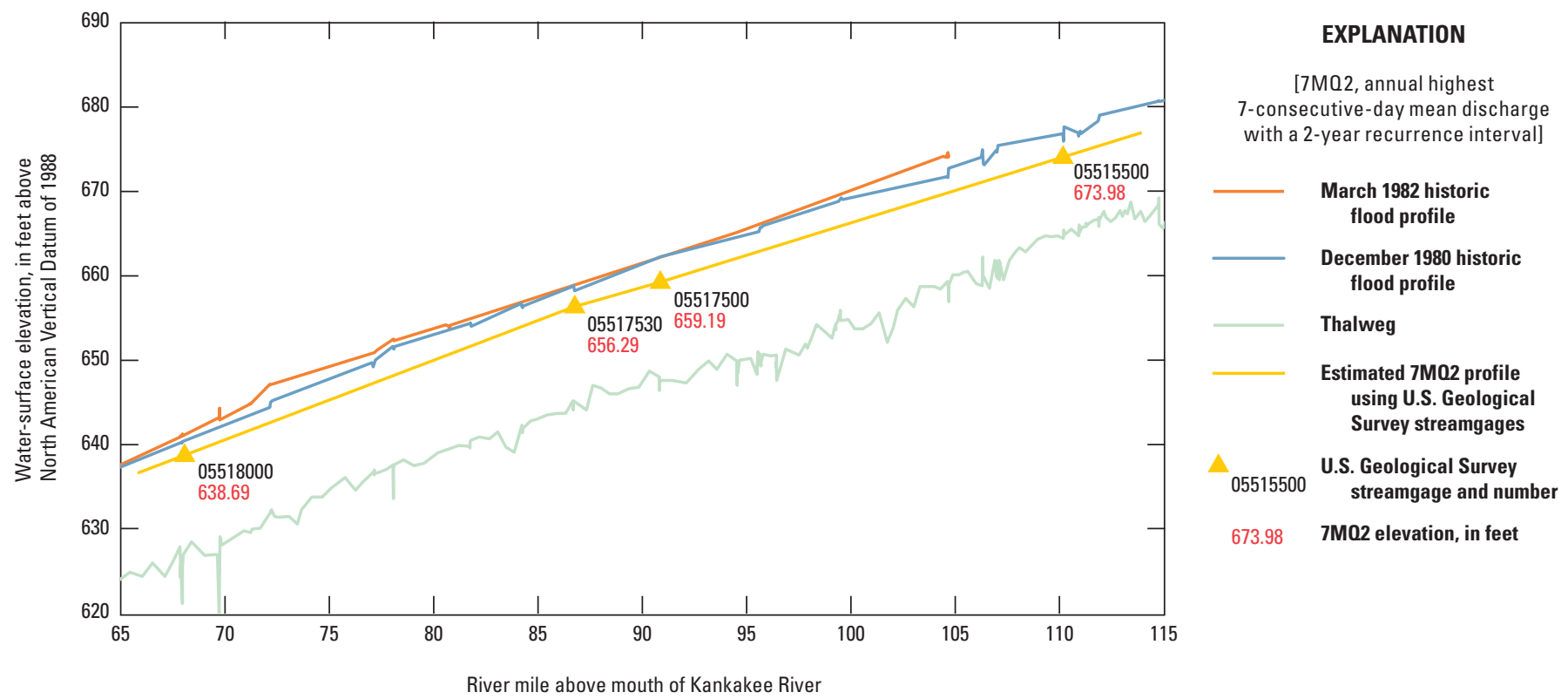

Figure 3. Comparison of historical flood profile elevations to estimated 7M02 elevations along the Kankakee River in Indiana.

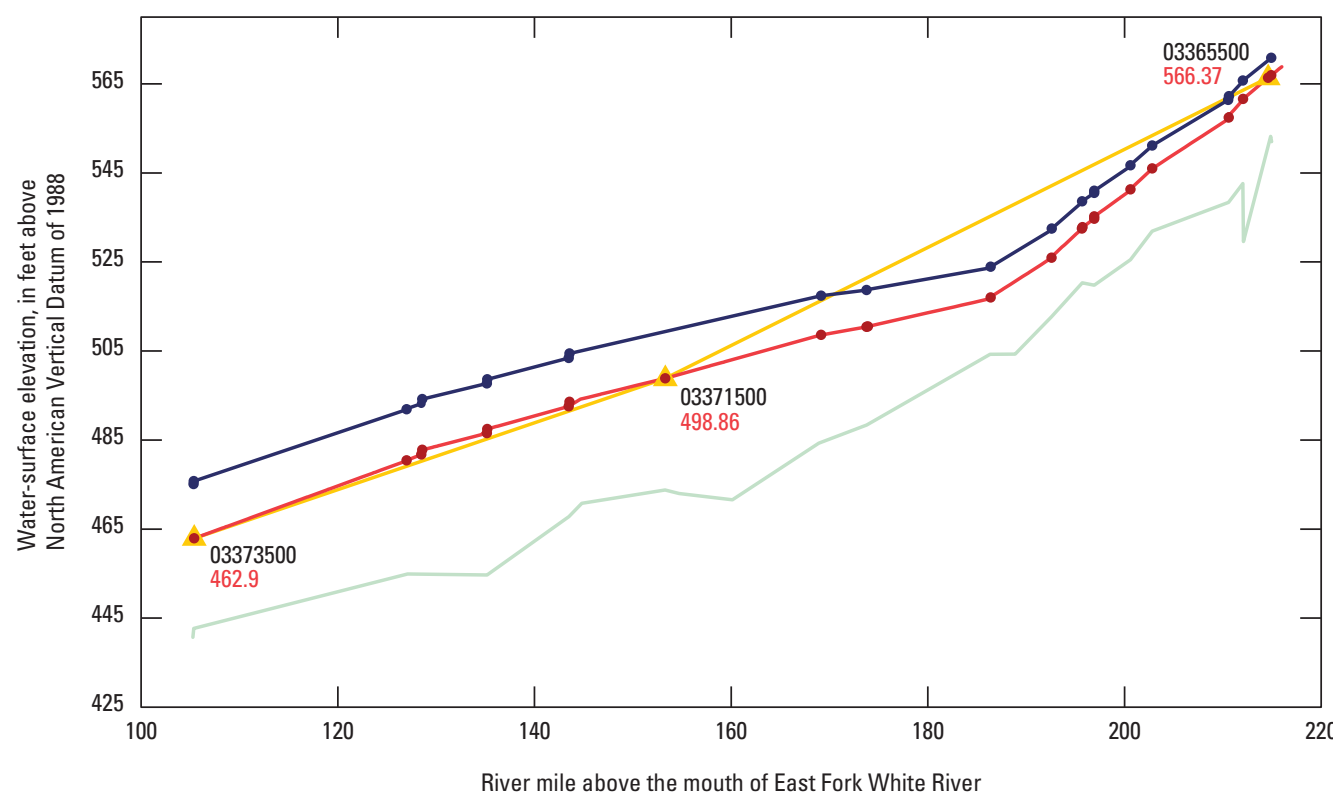

EXPLANATION

$7 \mathrm{M} 02$, annual highest 7-consecutive-day mean discharge with a 2-year recurrence interval; HWM, high-water mark]

Estimated 7M02 profile using U.S. Geological Survey streamgages

Thalweg

$\longrightarrow$ January 2005 historic flood profile

- Estimated 7M02 profile using adjusted HWM data

05515500 U.S. Geological Survey streamgage and numbe

566.37

$7 \mathrm{M02}$ elevation, in feet

Figure 4. Comparison of historical flood profile elevations to estimated 7M02 (streamgages only) and 7M02 using high-water mark elevations along the East Fork White River in Indiana. 
high-water marks to a level commensurate with the 7MQ2 streamflow, the difference in elevation between the historical flood and the known 7MQ2 elevation at the location of a USGS streamgage was subtracted from all high-water marks that make up the historical flood profile. This process was repeated for each individual streamgage on the study reach to produce as many adjusted profiles as streamgages. Adjusting the elevations in this way preserves the stepwise pattern of the historical flood and shifts the water surface profiles to align with and pass through their respective streamgages. Distance-weighted averaging was then applied to merge each of the adjusted profiles into one profile that assigns greater weight to nearby streamgages in estimating 7MQ2 elevations at unknown locations, and thus ensures the interpolated profile passes through the known 7MQ2 elevations at all streamgage locations.

All 12 stream reaches were graphically analyzed using historical flood profiles and the 4 checks for validity listed above. Not all stream reaches required an adjustment or calibration if none of the conditions were violated. Dates of historical flood events and summaries of the number and coverage of high-water marks along the three study reaches where they were used as supplemental data are provided in table 2. The precise locations of the high-water marks used are provided in the data release for the three study reaches listed.

\section{Uncertainties and Limitations Regarding Use of Wetland Inundation Maps}

The wetland inundation maps represent the boundaries of inundated areas with a distinct line; however, some uncertainty is associated with these maps. The boundaries shown are estimated on the basis of streamflow statistics at USGS streamgages. The 7MQ2 streamflow statistic represents the mean value of the 7-day high flow. The estimated inundation area would probably not be under water for the entire 7 days, but areas that could be inundated are less likely to be missed using this statistic. Additional areas may be inundated because of unanticipated conditions such as backwater from a main stem river, blockage of water because of earthen embankments, or backwater from localized debris. Conversely, some areas that should be shown as inundated may not be because of changes in the streambed elevation or roughness. The accuracy of the inundation extent portrayed on these maps also will vary with the accuracy of the digital elevation model used to simulate the land surface.

As distance from a streamgage increases, so does the uncertainty of interpolated water-surface elevations. The overall accuracy of interpolation throughout a study reach is affected by the number and spacing of streamgages as well as the coverage of supplementary data points such as high-water marks. Changes in the slope of the water-surface profile may go unobserved without sufficient coverage of data points. To the extent possible, high-water marks from historical floods were used to validate results; however, distances between the high-water marks vary from a few feet to many miles. In general, data points at or near major inflections in the slope of the water surface are of greater value than those on parts of a stream with relatively unchanging slope.

The angles at which stream transects intersect with the fluvial plain contribute some uncertainty to inundation results given that the way they are drawn affects how water-surface elevations are extrapolated outwards from the main channel. Effort was made to draw transects that are perpendicular to the direction of flow, but highly sinuous or meandering streams present challenges to the automated methods that compute flow direction azimuths based on stream geometry. Areas having relatively small differences in elevation between the estimated 7MQ2 water surface and the land surface, such as areas near the boundary of the estimated wetlands, would be more sensitive to variations in the angles at which transects are drawn. With all other parameters held equal, differences in how transects are drawn could produce variability in the results, which may be less pronounced in constricted parts of a stream reach and more pronounced where the fluvial plain widens.

Table 2. River reaches that required the use of high-water marks for calibration of the $7 \mathrm{M02}$ profile.

[7MQ2, annual highest 7-consecutive-day mean discharge with a 2-year recurrence interval; mi, mile]

\begin{tabular}{lcccccc}
\hline \multicolumn{1}{c}{ River reach } & $\begin{array}{c}\text { Downstream } \\
\text { river mile }\end{array}$ & $\begin{array}{c}\text { Upstream } \\
\text { river mile }\end{array}$ & $\begin{array}{c}\text { Number of high- } \\
\text { water marks' used } \\
\text { as inflection points }\end{array}$ & $\begin{array}{c}\text { Average distance } \\
\text { botween and year } \\
\text { of historical flood }\end{array}$ & $\begin{array}{c}\text { Maximum distance } \\
\text { between } \\
\text { high-water marks } \\
\text { (mi) }\end{array}$ & $\begin{array}{c}\text { bigh-water marks } \\
\text { (mi) }\end{array}$ \\
\hline East Fork White River & 105.4 & 214.6 & 43 & January 2005 & 2.6 & 21.6 \\
Upper Wabash River & 387.2 & 445.2 & 46 & July 2003 & 1.3 & 18.3 \\
Wildcat Creek & 4.8 & 79.9 & 79 & June 1958 & 0.9 & 10.4 \\
\hline
\end{tabular}

${ }^{1}$ High-water marks from Indiana Department of Natural Resources Historical Flood Profiles (written commun.). 


\section{Transferability of Methods}

The methods described in this report for determining potential locations for wetland restorations could be used by other States and regions to help administer important national programs to restore and protect wetlands. Because of the widespread availability of the data resources used for this project, including high-resolution digital elevation model data, historical flood profiles, and a national network of about 8,200 USGS streamgages, this project has great transferability potential.

\section{Summary}

The U.S. Geological Survey (USGS), in cooperation with the U.S. Department of Agriculture, Natural Resources Conservation Service, completed a study to estimate the potential wetland extents for 12 river reaches in Indiana and parts of Illinois and Ohio. The reaches were selected by the USGS and the Natural Resources Conservation Service as river basins that contain two or more USGS streamgages and are in areas where potential wetland information is needed for restoration under the Agricultural Conservation Easement Program.

Streamflow statistics were obtained through statistical analysis of daily mean discharges stored for USGS streamgages. The statistical value generated for this analysis is the annual highest 7-consecutive-day mean discharge with a 2 -year recurrence interval. This statistical value is referred to as the "7MQ2." The 7MQ2 at a streamgage serves as a determination of the inundation flow at that location. For this study, the 7-consecutive-day mean discharge time-series data were analyzed using a log-Pearson Type-III distribution, as implemented in the USGS software package SWToolbox.

Water-surface elevations of the 7MQ2 flows were determined using the stage-discharge rating for each of the streamgages used in this study. Once the inundation flow was determined, the corresponding elevation of that flow was selected from the rating. The most recent rating or the rating used during the period of record of the streamgage was used. The validity of the elevations and the resulting water-surface profiles was checked using a visual comparison with Indiana Department of Natural Resources historical flood profiles at each stream reach.

Once the inundation elevations were estimated for the river reach, flood maps were developed in conjunction with digital elevation model data. A series of water-surface planes was created using a geographic information system application to represent the surface of inundation elevation that sloped in the downstream direction of flow. After the surface of the inundation zone was generated, a map representing the inundation zone was created by subtracting the digital elevation model from the surface of inundationelevation data.
The workflow for the 2012 pilot study for the mapping of wetland extent was reproduced programmatically using Python, an open-source, object-oriented programming language. Scripts named "Draw Transects" and "Delineate Wetlands" were written and configured as geoprocessing tools in an ArcGIS Python toolbox (.pyt). Development of the toolbox was in part motivated by a need to make the workflow more time efficient, but also to allow reproducibility of the results when using an identical set of parameters and to improve documentation of the process.

Wetland mapping is important for wetland inventory, regulation, management, protection, and restoration. The National Resources Conservation Service and its partners use inundation-zone verification for the Agricultural Conservation Easement Program. The emphasis of this program is to protect, restore, and enhance the functions and values of wetland ecosystems. Because data resources used for this project-including digital elevation model data, flood profiles, and a national network of about 8,200 USGS streamgages - are widespread, this project has great transferability potential to other States and regions across the country.

\section{Selected References}

Cowardin, L.M., Carter, V., Golet, F.C., and LaRoe, E.T., 1979, Classification of wetlands and deepwater habitats of the United States: Washington, D.C., U.S. Department of the Interior, Fish and Wildlife Service, FWS/OBS-79/31, 142 p., accessed June 2017 at https://www.fws.gov/wetlands/documents/classification-of-wetlands-and-deepwaterhabitats-of-the-united-states.pdf.

Dahl, T.E., 1990, Wetland losses in the United States 1780s to 1980s: Washington, D.C., U.S. Department of the Interior, Fish and Wildlife Service, 13 p., accessed October 9, 2018, at https://www.fws.gov/wetlands/Documents/WetlandsLosses-in-the-United-States-1780s-to-1980s.pdf.

Fowler, K.K., Sperl, B.J., and Kim, M.H., 2019, Data sets related to wetland extent maps for 12 stream reaches covering approximately 750 river miles in Indiana: U.S. Geological Survey data release, https://doi.org/10.5066/P9LGXDJ8.

Illinois Natural Resources Geospatial Data Clearinghouse, Illinois State Geological Survey, 2018, Illinois height modernization (ILHMP) — LiDAR data: Illinois State Geological Survey, Illinois Natural Resources Geospatial Data Clearinghouse, digital data, accessed September 2018 at http:// clearinghouse.isgs.illinois.edu/data/elevation/illinois-heightmodernization-ilhmp-lidar-data.

Indiana Department of Natural Resources, 1996, Indiana wetlands conservation plan: Indiana Department of Natural Resources, 75 p., accessed August 16, 2018, at http://www. in.gov/dnr/fishwild/3350.htm. 
Kiang, J.E., Flynn, K.M., Zhai, T., Hummel, P., and Granato, G., 2018, SWToolbox-A surface-water tool-box for statistical analysis of streamflow time series: U.S. Geological Survey Techniques and Methods, book 4, chap. A11, 33 p., accessed May 2018 at https://doi.org/10.3133/tm4A11.

Kim, M.H., Ritz, C.T., and Arvin, D.V., 2012, Method for estimating potential wetland extent by utilizing streamflow statistics and flood-inundation mapping techniques-Pilot study for land along the Wabash River near Terre Haute, Indiana: U.S. Geological Survey Scientific Investigations Report 2012-5175, 15 p., 1 app., accessed June 2017 at https:/pubs.usgs.gov/sir/2012/5175/.

Ohio Geographically Referenced Information Program, 2018; Ohio spatial data infrastructure-OSDI downloads: Ohio Geographically Referenced Information Program, digital data, accessed June 2017 at https://ogrip.oit.ohio.gov/ServicesData/GEOhioSpatialInformationPortal/OhioSpatialDataInfrastructure-Downloads.aspx.

Rantz, S.E., and others, 1982, Measurement and computation of streamflow: U.S. Geological Survey Water-Supply Paper 2175, v. 1-2, 631 p., accessed May 2017 at https://pubs. usgs.gov/wsp/wsp2175/.

Riggs, H.C., 1968, Frequency curves: U.S. Geological Survey Techniques of Water-Resources Investigations, book 4, chap. A2, 15 p., accessed August 2017 at https://pubs.usgs. gov/twri/twri4a2/pdf/twri_4-A2_a.pdf.

Ruddy, B.C., and Hitt, K.J., 1990, Summary of selected characteristics of large reservoirs in the United States and Puerto Rico: U.S. Geological Survey Open-File Report 90-163, 295 p., accessed June 2017 at https://pubs.usgs. gov/of/1990/0163/ofr19900163.pdf.

U.S. Department of Agriculture, 1994, Wetland mapping conventions for agricultural land and narrow band and small pocket inclusions of non-agricultural land: Indianapolis, Ind., U.S. Department of Agriculture, Soil Conservation Service, 31 p., accessed July 2017 at https://www.nrcs.usda. gov/Internet/FSE_DOCUMENTS/nrcs144p2_030528.pdf.

U.S. Department of Agriculture, 2007, Making wetland determinations on agricultural land: U.S. Department of Agriculture, 8 p., accessed August 9, 2018, at https://www.nrcs. usda.gov/Internet/FSE_DOCUMENTS/nrcs144p2_030893. pdf.

U.S. Department of Agriculture, 2013, Summary report_-2010 National Resources Inventory: Washington, D.C., U.S. Department of Agriculture, Iowa State University, 155 p., accessed February 2018 at https://www.nrcs.usda. gov/Internet/FSE_DOCUMENTS/stelprdb1167354.pdf.
U.S. Department of Agriculture, 2017, 2014 farm billAgricultural Conservation Easement Program-NRCS: U.S. Department of Agriculture web page, accessed October 31, 2018, at https://www.nrcs.usda.gov/ wps/portal/nrcs/detail/national/programs/easements/ acep/?cid=stelprdb1242695.

U.S. Department of Agriculture, 2018, Restoring America's wetlands - A private lands conservation success story: U.S. Department of Agriculture, 16 p., accessed September 2018 at https://www.nrcs.usda.gov/Internet/FSE_DOCUMENTS/stelprdb1045079.pdf.

U.S. Fish and Wildlife Service, 2004, Questions and answer about - Status and trends of wetlands in the conterminous United States 1998 to 2004: U.S. Fish and Wildlife Service, accessed February 2017 at https://www.fws.gov/wetlands/ Documents \% 5CQuestions-and-Answers-About-Status-andTrends-of-Wetlands-in-the-Conterminous-United-States1998-to-2004.pdf.

U.S. Geological Survey, 1996, National water summary on wetland resources: U.S. Geological Survey Water Supply Paper 2425, 431 p., accessed October 15, 2017, at https:// pubs.usgs.gov/wsp/2425/report.pdf.

U.S. Geological Survey, 2011, SWSTAT, Surface-water statistics, accessed October 8, 2018, at https://water.usgs.gov/ software/SWSTAT/.

U.S. Geological Survey, 2017, USGS National Hydrography Dataset (NHD) best resolution 20170530 for Indiana State or territory file GDB 10.1 model version 2.2.1: U.S. Geological Survey, digital data, Data.gov web page, accessed January 2018 at https://catalog.data.gov/dataset/usgs-national-hydrography-dataset-nhd-best-resolution-20170530-for-indiana-state-or-territory-f.

U.S. Geological Survey, 2018a, USGS water data for the Nation: U.S. Geological Survey National Water Information System database, accessed December 2018 at https://doi. org/10.5066/F7P55KJN.

U.S. Geological Survey, 2018b, Geographic Names Information System (GNIS) - USGS national map downloadable data collection: U.S. Geological Survey, digital data, accessed November 2018 at https:/catalog.data.gov/dataset/ geographic-names-information-system-gnis-national-geospatial-data-asset-ngda-geographic-names-.

Woolpert, Inc., 2011, Indiana statewide digital orthoimagery: Woolpert, Inc., prepared for Indiana University, Woolpert Order No. 71177, raster digital data, accessed June 2017 at http://gis.iu.edu/files/documents/in2011_ortho.txt. 
Publishing support provided by:

Madison and Rolla Publishing Service Centers

For additional information concerning this publication, contact:

Director, Ohio-Kentucky-Indiana Water Science Center

U.S. Geological Survey

5957 Lakeside Boulevard

Indianapolis, IN 46278

(317) 290-3333

Or visit the Ohio-Kentucky-Indiana Water Science Center website at: https://www.usgs.gov/centers/oki-water 


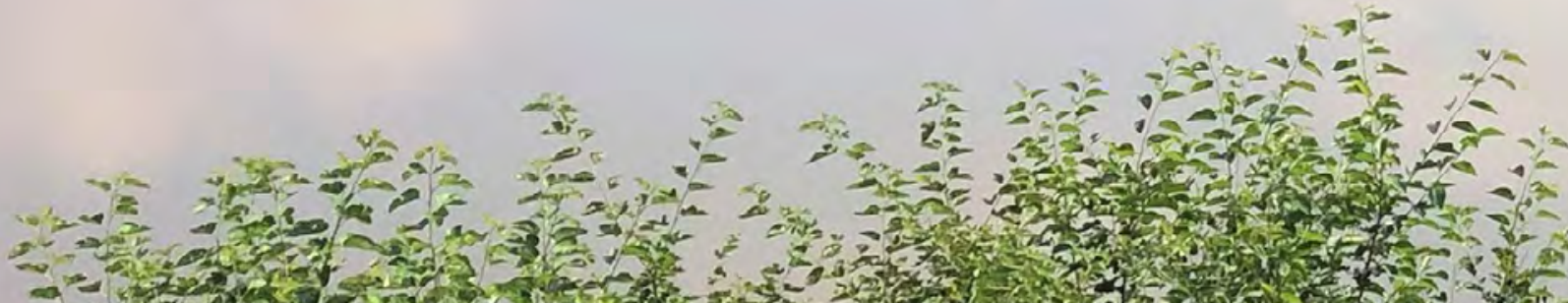

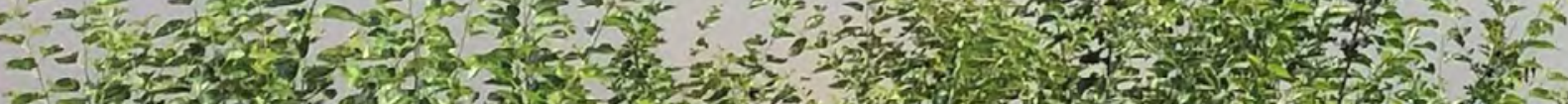
$\frac{1}{3}-3$ - 